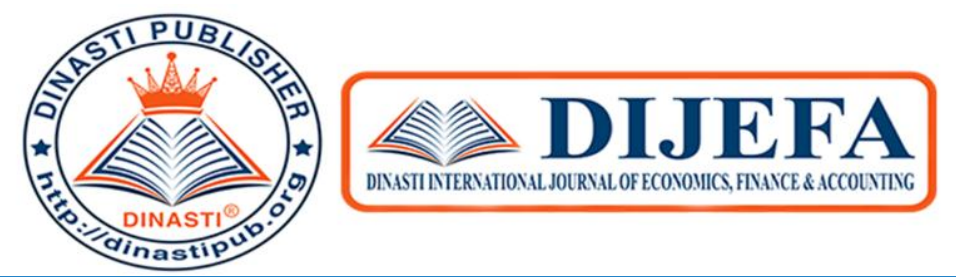

+6281387654578 ()

+6281387654578 @

https://dinastipub.org/DIJEFA (7)

dinasti-info@gmail.com @.

\title{
BUSINESS DIFFERENTIATION STRATEGY OF ANTIMICROBIAL PRODUCTS IN THE COVID-19 PANDEMIC
}

\author{
Judiatin Rachmiarti Kusumah \\ ${ }^{1)}$ Universitas Mercu Buana, Jakarta, Indonesia
}

\begin{tabular}{|c|c|}
\hline $\begin{array}{l}\text { Corresponding author: first author } \\
\text { E-mail: } \\
\text { judiatin@gmail.com }\end{array}$ & $\begin{array}{l}\text { Abstract : The Covid- } 19 \text { pandemic that has struck the world } \\
\text { worldwide has had a major impact, particularly on the economic } \\
\text { and socio-cultural conditions of every person in every country. No } \\
\text { exception in Indonesia, which has not escaped and is also affected } \\
\text { by the global pandemic. There is a slowdown in the growth } \\
\text { process in the economic and financial sectors. This is the result of } \\
\text { efforts to stop the spread of the virus with a lock-down action } \\
\text { country in the world, and the implementation of the WFH (Work } \\
\text { From Home) program and the PSBB (Large-Scale National } \\
\text { Limitation) in Indonesia is having an effect for most industrial } \\
\text { companies to slow down the business. This situation has a major } \\
\text { impact on conditions in almost all companies where business is } \\
\text { slowing down. There has also been a decline in activity in } \\
\text { manufacturing companies producing paints, as consumer demand } \\
\text { for paint products has been drastic due to the many delays in the } \\
\text { process of building and building, and the process of painting } \\
\text { houses and buildings has been stopped by painters. PT XYZ } \\
\text { Raya, a national paint company that realizes competitive } \\
\text { advantages between paint manufacturers, develops a } \\
\text { differentiation strategy for paint products that meets the } \\
\text { conditions and needs of paint consumers under the current } \\
\text { pandemic conditions, namely antimicrobial paint products that } \\
\text { can prevent this and inhibit the growth of viruses, germs and } \\
\text { bacteria on the walls of our houses. So that family health can be } \\
\text { maintained by using these antimicrobial wall paint products. The } \\
\text { product differentiation strategy, in this case wall paint, is an } \\
\text { embodiment of one of the company's competitive strategies } \\
\text { according to Michael Porter's generic strategy. } \\
\text { Keywords: Differentiation strategy, Michael Porter's generic } \\
\text { strategy, antimicrobial color, economic situation, business } \\
\text { slowdown. }\end{array}$ \\
\hline
\end{tabular}

\section{INTRODUCTION}

Since the World Health Organization (WHO) officially announced the outbreak of Covid-19 as a global pandemic on March 11, 2020, the virus has infected almost everyone in 
this hemisphere, from Asia, Europe, the United States to Africa. This has an impact on the global economic situation. The global economic situation has deteriorated due to the increasing number of countries affected by the Covid 19 virus worldwide. The International Monetary Fund (IMF) forecasts a weakening of the global economy with a forecast for a growth of the global economy of minus $3 \%$.

In March 2020, government revenue growth grew positively, according to the finance minister, but the government was still concerned about the impact of the pandemic the following month. General growth in the tax revenue component continued to be overshadowed by pressure from the slowdown in manufacturing and international trade, and the slowdown in economic activity due to the spread of Covid-19.

The use of Work From Home (WFH) in government and the private sector has slowed business. This situation can lead to a decrease in domestic delivery, which will reduce the receipt of domestic VAT (PPNDN) in April 2020. Together with the introduction of largescale social restrictions (PSBB) in several areas in April, this economic situation is expected to continue until the end of the year in May.

This outbreak has had side effects on the social and cultural environment of our society. Initially, the community did not like to stay at home, but now people have to try to feel at home. One of the major changes in people's behavior is the appearance of attitudes in the community that are increasingly sensitive to things that are normally not important to us, e.g. B. the cleanliness of the house. Whatever happens, hopefully this epidemic will end soon and we will become a better person.

\section{LITERATURE REVIEW}

\section{Michael Porter's Generic Strategy}

According to Porter (1994, p. 9), a competitive advantage can only be achieved by one of two sources:

- can benefit from creating a low cost (cost leadership) or

- the ability of the organization to differentiate itself from its competitors (differentiation).

These two factors form the basis for Porter's generic competitive strategy:

(a) cost leadership strategy (cost leadership),

(b) differentiation strategy and

(c) focus strategy (cost-based or differentiation)

\section{a. Cost management strategy}

The strategy of an organization or company to become the market leader with a low cost base and a broad customer base. The costs here are the total production costs and not the price.

The advantages of a cost leadership strategy: 
- Companies that implement a low-cost strategy can generate above-average income, even though competition in the market is very tight.

- As a market leader, implementing a cost-effective strategy gives it the flexibility to work with its suppliers.

Lack of cost leadership:

- Cost leadership strategies strongly depend on the ability of competitors to mimic the success of differentiating product strategies.

- Companies can be caught by differentiating their products too much.

\section{b. Differentiation strategy}

The company follows a differentiation strategy if the company wants to compete with its business competitors in terms of the unique products and services offered. The differentiation takes the form of differences with regard to:
$\checkmark$ Prestige
$\checkmark$ technology
$\checkmark$ innovation
$\checkmark$ functions
$\checkmark$ Customer service
$\checkmark$ Dealer dealer network

Weaknesses in the differentiation strategy:

- The differentiation strategy depends heavily on the ability of competing companies to mimic and mimic the success of product differentiation strategies.

- Companies can be caught if they differentiate their products too much.

- An incorrect application of differentiation can damage the image of the company itself.

\section{c. Focus strategy}

Companies that implement a focus-oriented strategy by serving the needs of a specific market segment (niche market). Companies can implement a cost-based or differentiation-based focus strategy. The difference lies in the smaller segmentation

Strengths of the focus strategy:

- There are fewer competing companies and sellers have weak bargaining power if the company has positioned its products in a less price-sensitive market segment

- Companies that implement a focus strategy must understand and fully understand the market segment

Weakness in focus strategy:

- Differentiation-based companies can jeopardize the company's strategic direction by taking the segment position in the market. 
- The taste and needs of consumers for their products are changing

- Companies that are still operating on a small scale implement a focus strategy, so efforts to significantly reduce production costs are not easy.

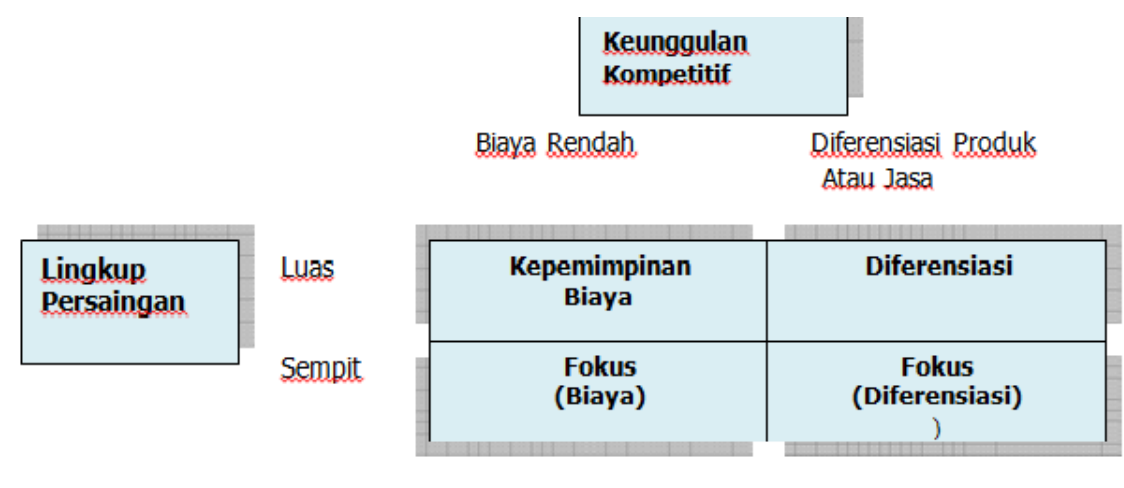

Image of the generic Porter strategy

Source: Michael E. Porter (1985)

The following are the differences between the cost management strategy, the differentiation strategy and the focus strategy:

\begin{tabular}{|c|c|c|c|}
\hline & Cost Leadership & Diferentiation & Focus \\
\hline Definition & $\begin{array}{l}\text { As a low-cost } \\
\text { producer in the } \\
\text { industry }\end{array}$ & $\begin{array}{l}\text { Trying to be a unique } \\
\text { company in the } \\
\text { industry }\end{array}$ & $\begin{array}{l}\text { Companies that compete } \\
\text { in a tight competitive } \\
\text { environment in an } \\
\text { industry }\end{array}$ \\
\hline $\begin{array}{l}\text { Coverage of } \\
\text { market share }\end{array}$ & Big & Big/small & Small \\
\hline $\begin{array}{l}\text { Competitive } \\
\text { coverage }\end{array}$ & Big & Big/small & Small \\
\hline $\begin{array}{l}\text { The strategy } \\
\text { used }\end{array}$ & $\begin{array}{l}\text { Based on consumer } \\
\text { prices }\end{array}$ & $\begin{array}{l}\text { Based on consumer } \\
\text { demand }\end{array}$ & $\begin{array}{l}\text { Concentrate on a } \\
\text { product/service segment }\end{array}$ \\
\hline $\begin{array}{l}\text { The result } \\
\text { achieved }\end{array}$ & $\begin{array}{l}\text { Production/service } \\
\text { costs are low, so the } \\
\text { price of selling } \\
\text { products/services is }\end{array}$ & $\begin{array}{l}\text { The products/services } \\
\text { produced are unique } \\
\text { and differ from the } \\
\text { products/services of }\end{array}$ & $\begin{array}{l}\text { The products/services is } \\
\text { superior to other } \\
\text { competing } \\
\text { products/services }\end{array}$ \\
\hline
\end{tabular}




\begin{tabular}{|l|l|l|l|}
\hline & $\begin{array}{l}\text { relatively low } \\
\text { compared to other } \\
\text { competitors }\end{array}$ & other competitors & $\begin{array}{l}\text { because it focuses on a } \\
\text { specific product } \\
\text { segment }\end{array}$ \\
\hline Sales Price & Low & High & $\begin{array}{l}\text { Can br low but can also } \\
\text { be high }\end{array}$ \\
\hline
\end{tabular}

Product differentiation strategy, that encourages companies to find specific uniqueness in certain market segments. This type of strategy is usually aimed at potential consumers who do not give prices a priority when making their decisions (price-insensitive). The differentiation strategy does not guarantee a competitive advantage for the company.

\section{Risk differentiation strategies:}

$\checkmark$ Standard products that were previously in circulation on the market and can meet the needs of consumers or competitors / competitors of companies that can imitate in a very short time. Applying this differentiation strategy is better suited for products that are durable and difficult for competitors to imitate.

$\checkmark$ When the difference or uniqueness of the product that is deliberately created and offered to consumers is obviously not in demand by consumers. So that competing companies that offer standard products with cost-effective strategies can easily conquer this market share.

\section{Business Strategy Differentiation}

The differentiation strategy is an organizational strategy that aims to produce a product or service that is different from products or services of other companies. In other words, the product or service produced must have an identity. The identity of this product or service can be in the form of attributes associated with the product or service so that they are known to the customer. The main focus of the differentiation strategy is on customer loyalty to the company's product or service.

According to Kodrat (2009), a differentiation strategy focuses more on customers than on costs. This strategy aims to improve customers' perceptions of quality, product design, technology, distribution networks, weight, materials and services. If the company implements this strategy, it can raise prices to get the best possible profit, but must develop products that look different to customers than other existing products.

Porter (2007) may base the differentiation on the product itself, the product delivery system used for sale, the marketing approach, and a variety of other factors.

Differences or characteristics that are inherent in a product often reflect higher prices compared to other products that are not differentiated.

The following skills and resources are required to implement the differentiation strategy (Kodrat 2009): 
- Strong marketing skills

- Creative talent

- Product development

- Ability to perform excellently in research

- Corporate reputation for quality leadership and technology

- The old tradition prevails in an industry

- Strong collaboration between the channels

The implementation of the differentiation strategy requires skills and the optimal strengthening of company resources. The company's strong marketing skills and support from reliable marketing staff will enable the company to expand the marketing area, increase the number of loyal customers and increase the number of potential customers.

For this reason, innovation and creativity are continuously needed by the research and development department so that customers can feel the uniqueness of different products. The process of creating or designing a product or service requires the company's talent, innovation and creativity. Companies need to prepare research costs to create product or service innovations. In addition to budgeting the cost of research and development, companies must also hire experts to develop products and costs for the use of technology.

\section{Advantages of differentiation strategies}

Products offered by companies that implement differentiation strategies must have a specific differentiation from competing products, as this is advantageous compared to competing products.

1. With the differentiation, the product life cycle becomes longer

In order to increase sales again, a product must be differentiated in which a decline (decline) occurs and a decline in the marketing of the product or service is identified.

2. Differentiating products or services makes it easier for consumers to remember

Differentiating a product or service has a psychological impact on consumers, so it can be easily tied to the minds of consumers because it arouses consumer interest, namely the uniqueness that distinguishes the products or services we offer from competing products . Consumer curiosity will make consumers more interested in knowing the product or service, and will be interested in consuming the product or service.

3. The differentiation shows the advantages of the product or service compared to other products.

The uniqueness or difference of the products or services we offer gives consumers the view that the goods or services we manufacture are better than other products. Therefore, consumers are more interested in using the products or services manufactured by our company than other products.

4. The differentiation makes the sales value of the products or services we market higher than for other products

5. Overcome market saturation 
Product differentiation enables entrepreneurs and market participants to offer other variants of standard products that are usually offered to give consumers a feeling of satiety.

6. The creation of product images

The more unique the products on offer, the easier it is for consumers to recognize the product. Therefore, there is a great way to embed the product image on offer in the hearts of consumers. This enables the company to determine the correct positioning according to the target market.

The implementation of the differentiation strategy will also affect the survival of the company's reputation. This is because companies are competitive by developing products that are of better quality and even have advantages over products from other companies.

A differentiation strategy can also be developed if the company can work with supporting companies, for example companies that play a role in the delivery of products or services, such as: B. Agents and dealers. Working with a representative or distributor will shorten the product sales channels. Companies can also do direct sales by contacting consumers or end customers so consumers can easily get products.

\section{Weaknesses in differentiation strategies}

The most important thing to avoid when implementing a differentiation strategy is the tendency of companies to reduce product costs (cost-saving products) or not to continuously implement aggressive marketing plans, as this situation is a major weakness of this strategy. When customers start to believe this, the difference to competing products is no longer important, so lower product costs are more attractive to customers.

\section{RESEARCH METHODS}

In writing this paper, the author obtains data used in the paper using data collection methods in the form of literature studies, collecting data from multiple books, journals, and searching and collecting data over the Internet and annual reports. This method aims to provide the author's ideas and opinions to solve problems or case studies that occur in the present but are still focused on the actual problem.

\section{FINDINGS AND DISCUSSION}

\section{Consumer Behaviour}

The global pandemic conditions are not just affecting business and the world

In business, Covid-19 is also changing the behavior of people and consumers in our country. Consumers are increasingly concerned about health and hygiene and are increasingly consuming health products and vitamin drinks. The players in the vitamin and pharmaceutical industries took this opportunity. 


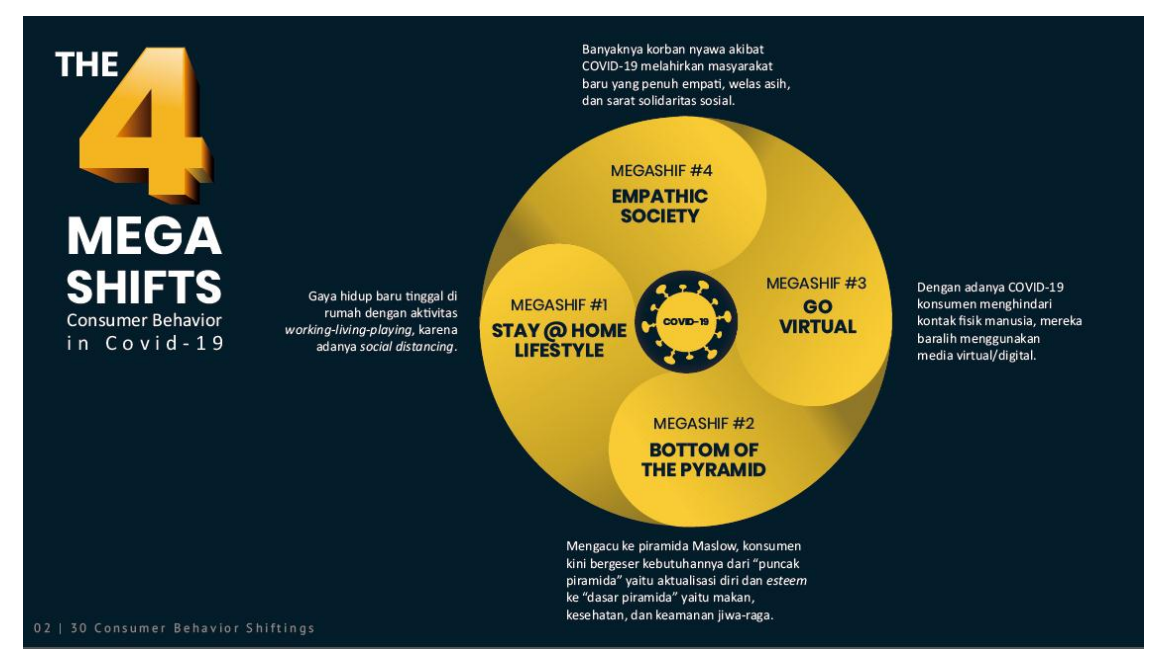

Inventory Knowledge predicts 4 types of shifts in consumer behavior known as "The 4 Mega Shifts in Consumer Behavior", namely:

1. Stay at home lifestyle

2. Bottom of pyramid

3. Go virtual

4. Empathic society

With the shift in consumer behavior of the pyramid, consumers are shifting to the basic needs of nutrition, health and body safety. Therefore, consumers' attention to hygiene and health products is increasing at this time.

\section{Business situation in the middle of the Covid 19 pandemic}

The Covid 19 virus pandemic threatened not only the health sector, but also the global economic crisis. According to the World Economic Outlook of April 2020, the IMF is forecasting a decline in the global economy to minus three percent this year. However, if this pandemic ends in the second half of 2020 and economic activity returns to normal, the Indonesian economy is expected to grow to $8.2 \%$ and the global economy by $5.8 \%$ (Tempo.Co, 2020).

The economic and industrial sectors are also affected. Changes in consumer behavior forced some business units to adapt to these conditions in order to survive with the following activities:

- Marketing strategies are turning to digital advertising

According to a Nielsen survey, around $80 \%$ of consumers search for Covid 19 news and information on social media and $60 \%$ on search engines. Advertising in digital media is an advertising method with a small budget, but it has a big impact (high impact). It can optimize a company's budget constraints and marketing strategy precisely to the goal.

- Change the strategy, not the budget (change the strategy, not the budget)

In a crisis situation, change the hard-selling strategy to soft-selling 
- Don't think outside the box. Think like there is no box

Marketing strategies need to be more creative.

In such a business situation, this is supported by changes in consumer behavior, where the public and consumers pay far more attention to issues related to hygiene and health. To realize its competitive advantage and respond to the situation, several companies have changed their business strategy towards Michael Porter's product differentiation strategy, including companies that manufacture colors. The company that produces paints develops innovative antimicrobial wall paint products (antibacterial, germs and fungi). Realization requires reliable $R \& D$ personnel to develop innovations and achieve a specific uniqueness of the products they manufacture, as this product differentiation strategy leads to the niche market of the products. This type of product has a high value, so manufacturers can sell at a higher price and consumers have no objection to buying the product. Because the products offered meet the criteria demanded by consumers, namely health for the home environment of the owner.

Antimicrobial wall paint specifications include:

- without smell

- Has antibacterial technology

- anti-germ

like the following antimicrobial wall paint products:

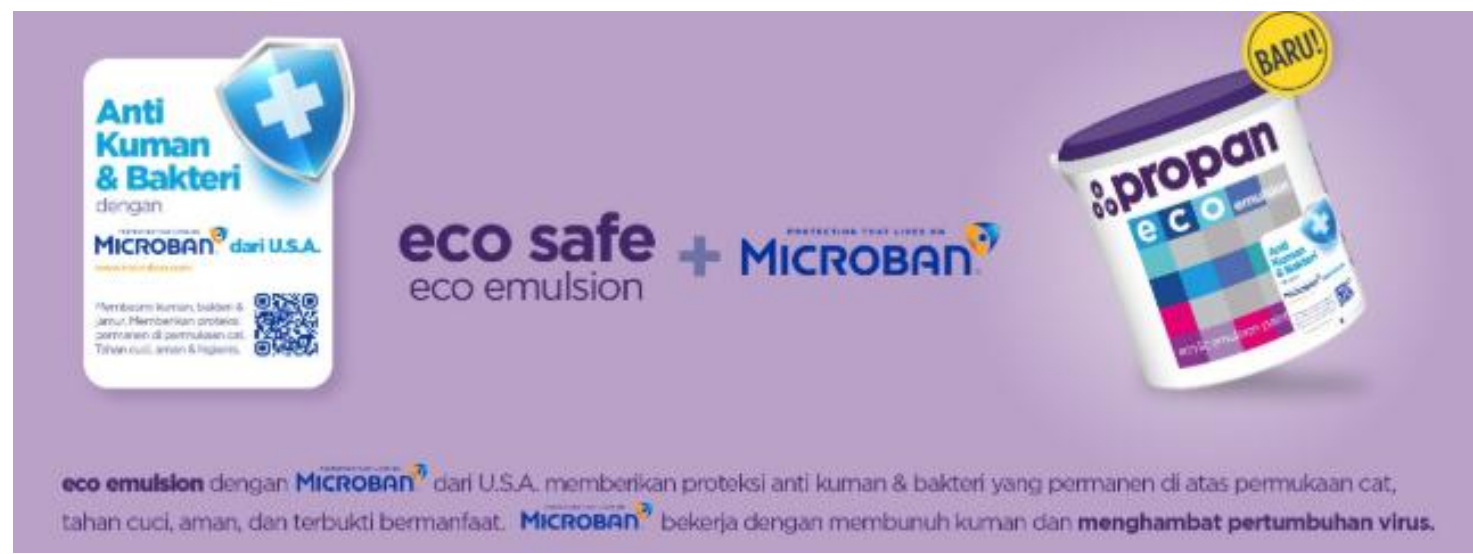

Gambar1. Produk Ecosafe Eco Emulsion 


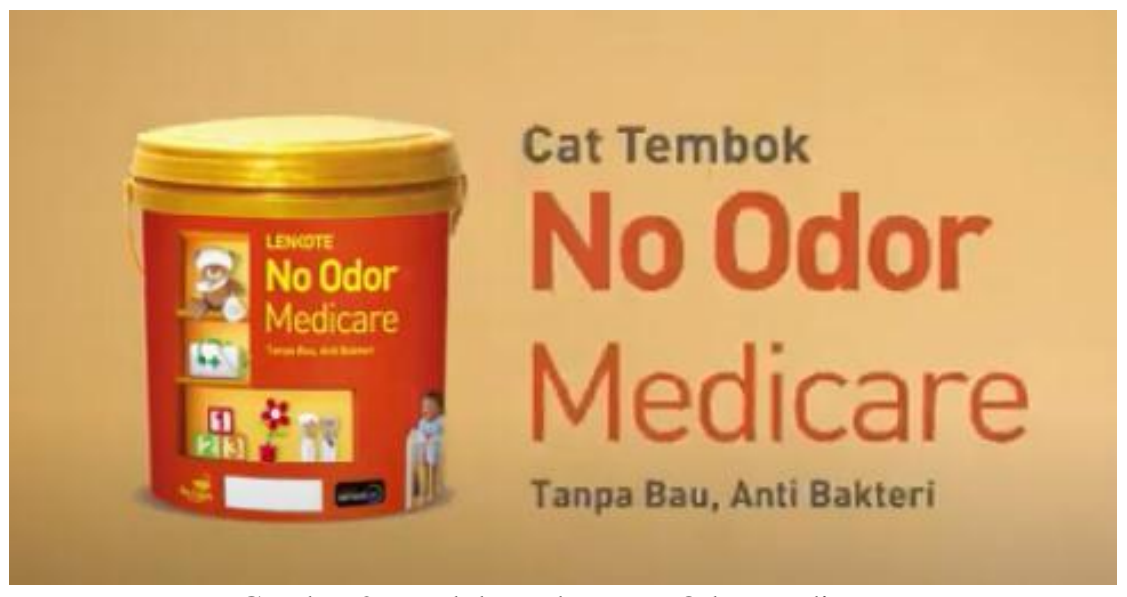

Gambar 2. Produk Lenkote No Odor Medicare

\section{NIPPON PRODUKBARUI}

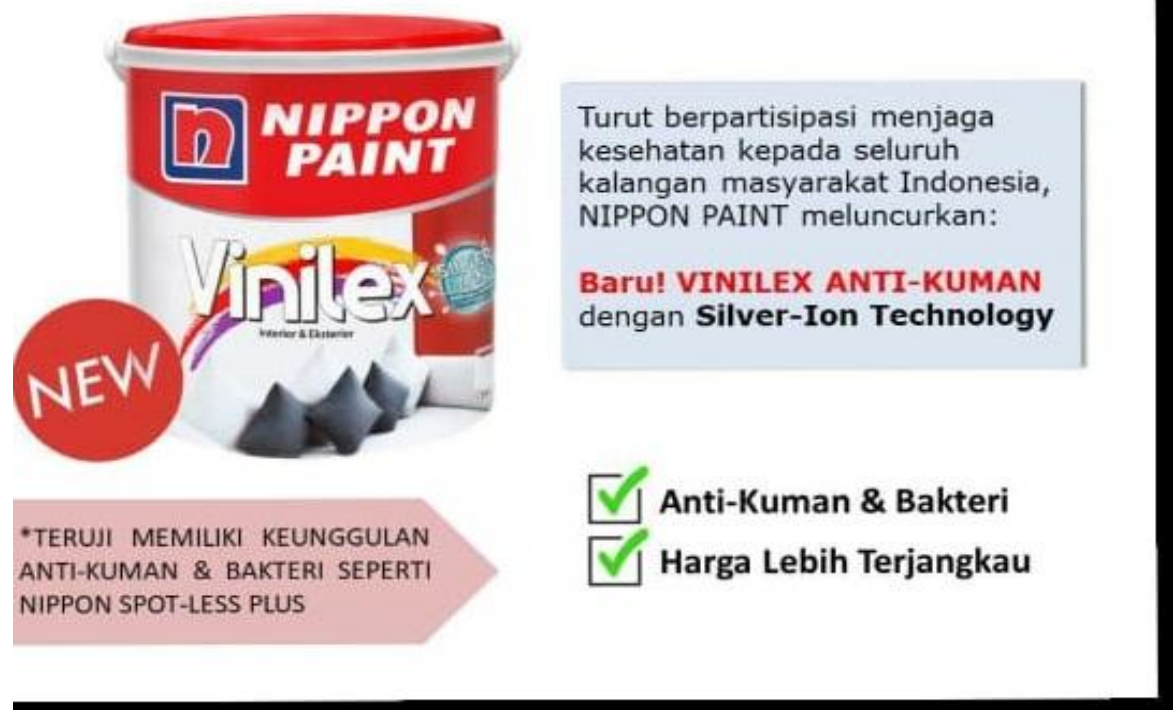

Gambar 3. Produk Vinilex Anti Kuman

\section{CONCLUSION AND SUGESTION}

PT XYZ Raya's innovative move to respond to the pandemic in Covid-19 that affects business and industrial sectors, in this case the company that manufactures paints. by implementing a product differentiation strategy as the company's competitive advantage strategy. The company is pursuing a differentiation strategy to compete with its competitors for the unique products it offers. Product differentiation, as one of the generic strategies proposed by Michael Porter at PT XYZ Raya, is carried out in the form of innovation, technology and product features, with the new product being offered to increase the company's sales and brand the company as innovative and responsive Conditions responding company to strengthen market around.

\section{Suggestion}


Given the changes in consumer behavior after this pandemic, it must be examined whether niche products with higher value will be more attractive to consumers in the future or not. In particular, products that are not consumer goods, as described in this paper, are wall paint products.

\section{REFERENCE}

1. Pearce, J.A. \& Robinson, R.B. (2013). Strategic Management, Formulation, Implementation and Control. Irwin Mc Graw-Hill Inc, Singapore.

2. Porter, M.E. (1980). Competitive Strategy : Techniques for Analyzing Industries and Competitors with a new introduction1 Michael E. Porter. New York, USA.

3. Ritson, Neil. (2013). Strategic Management. $2^{\text {nd }}$ Edition.

4. Sukrasno, Ali, H. (2018). Michael Porter's Generic Strategy. https://www.slideshare.net/SukrasnoSukrasno/6-sm-sukrasno-hapzi-ali-michael-portersgeneric-strategy-universitas-mercu-buana-2018 (10 April 2020, 14.00)

5. Gustianingty, Maharani, Ali, H. Strategi Generik Porter Secara Mendetail. https://www.slideshare.net/MaharaniGustianingty/6-sm-maharani-gustianingtyas-hapzi-alistrategic-management-strategi-generik-porter-secara-mendetail-universitas-mercu-buana2019 (10 April 2020, 14.00)

6. Ali, H. (2020). Michael Porter's generic Strategy. Modul Strategic Management, Universitas Mercubuana, Jakarta.

7. Mustamu, Ronny. (2009). Business Communication Leaders : Tipe-Tipe Strategi. https://mustamu.wordpress.com/2009/01/12/tipe-tipe-strategi/ (23 April 2020, jam 13.00).

8. Sari, Lia Permata. (2018). Apa yang Dimaksud dengan Strategi Diferensiasi? https://www.dictio.id/t/apa-yang-dimaksud-dengan-strategi-diferensiasi/116005 (23 April 2020, jam 13.00).

9. Lestari, Maria A.T. (2020). Dampak Sosial dari Wabah Covid-19 pada Budaya Masyarakat Sekitar. https://www.kompasiana.com/mariatari/5e841323d541df22db366d82/dampak-sosialdari-wabah-corona-covid-19-pada-budaya-masyarakat-sekitarnya\# (diakses 16 Mei 2020, jam 09.00).

10. Pers. (2020). Pemerintah Waspada Dampak Pandemi Covid-19 Terhadap Ekonomi Indonesia. Kementerian Keuangan Republik Indonesia, SP-27/KU/2020. https://www.kemenkeu.go.id/media/15072/sp-27-pemerintah-waspada-dampak-pandemicovid-19-terhadap-ekonomi-indonesia.pdf (diakses 16 Mei 2020, jam 09.00).

11. Tempo, Co. (2020). Strategi Mempertahankan Bisnis di Tengah Pandemi Covid-19. https://inforial.tempo.co/info/1002932/strategi-mempertahankan-bisnis-di-tengah-pandemicovid-19 (diakses 17 Mei 2020, jam 20.00). 